\title{
Not at home to visitors
}

\author{
They're big, but they're not clever.
}

\section{Janet Wright}

The guard stepped away from the small screen and said: "They're going. Come and look. The security manager hurried back, rubbing his eyes. If they really were going, he'd be glad of a good night's sleep. There was no real danger, of course - he'd kept assuring everyone of that. Hed almost convinced himself.

Intruders hadn't posed a serious threat in many years. But these were bigger than any previously seen or spoken of, and there was something different about them. He peered into the screen.

"That's a welcome sight," he said. A group of aliens was filing onto the strange craft that had caused so much interest when it arrived, followed by concern when its occupants began conducting a very thorough search. The people had learnt long ago that the best way of getting on with strangers was to avoid them. As their lifestyle made that easy, they rarely ran into trouble.

Aliens had come poking around before, but this group was using instruments the people hadn't previously seen. They were more technologically advanced than the earlier arrivals, that was for sure. There had been times when they'd almost stumbled on the ventilation system, and their heavy movements had shaken the rooms below.

They'd even found a toy that a child had left outside when she'd been playing in the moonlight the night before. She had wept over her lost birthday present, while her parents said: "It's your fault - you should have taken more care of it. You're not getting another one." Then, of course, security had sent a grab team and snatched it back for her.

The manager grinned at his guard. She was tousling the fur of a monkey that had brought another little trophy into the security room.

"You're brilliant with those monkeys," he said. The guard smiled modestly as she handed over the latest prize.

"They're intelligent and they like sweets. It's not hard to train them," she demurred. One of the monkeys had been caught but, true to its training, had gone limp until it saw its chance and leapt to freedom. "It was almost a shame seeing those aliens wondering who kept taking their equipment! ${ }^{\prime \prime}$

"Yes, that was funny. The stuff itself was a bit disappointing, though, very low-tech.

I thought they might have had a few devices worth looking at. Still, it's something new for the kids to play with."

The festival director hurried into the security room. "Is it true that they're going?" she panted.

The guard ushered her to the screen. ${ }^{\alpha}$ There you are. Can't make any promises, of course - we'll need to check that they're all gone and that they haven't left any nasty surprises."

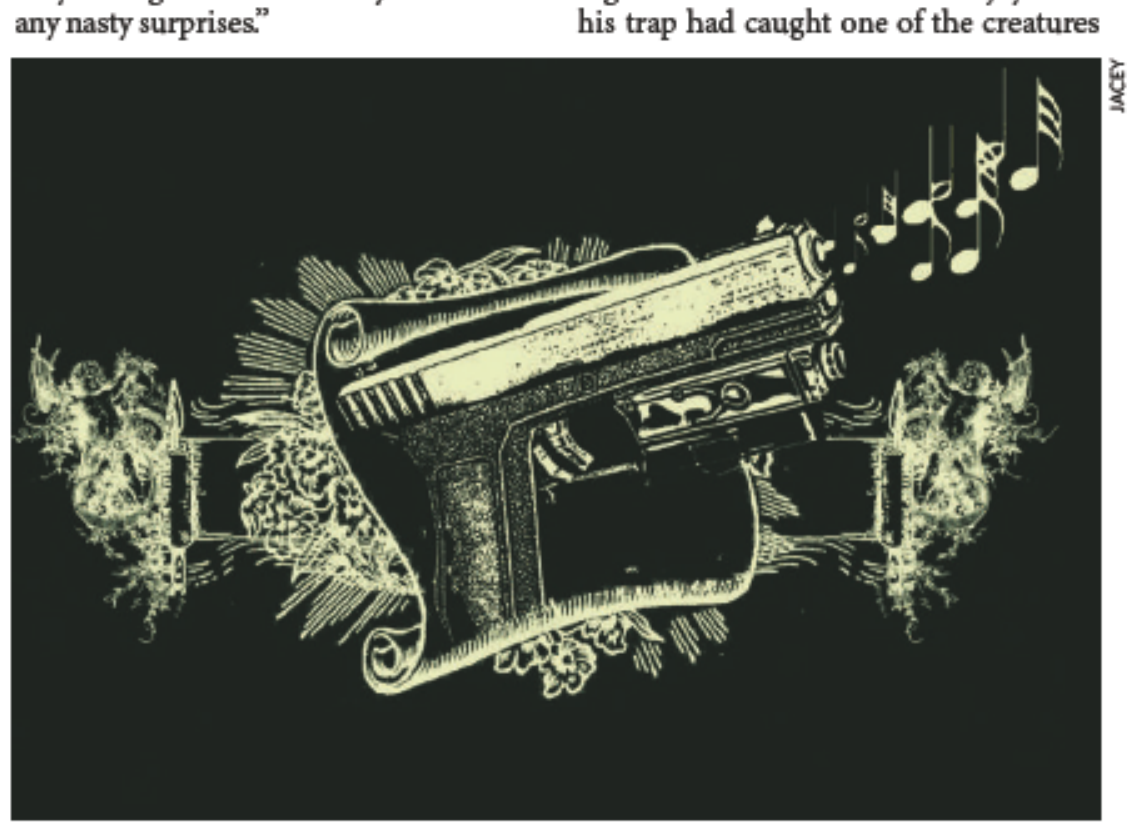

"Judging from the stuff we've seen so far, anything they've left should be easy to detect," said the security manager. "We've found a few micro-cameras already. It's not highly advanced stuff, but we'll get the monkeys to dismantle it all in case it's being monitored."

"So with luck, we should be clear by full moon then?" the festival director asked.

The others laughed. "That's the only thing that's bothered you, isn't it? That we'd have to delay the festival or hold it indoors!"

"Well, people put a lot of effort into their music, and there's no way around it, the best below-ground acoustics in the world aren't as good as outdoors on a clear moonlit night. Anyway, it's traditional. It's a pity those aliens didn't bring anything interesting," she added.

"You mean a musical instrument?" the guard teased her. ${ }^{\alpha}$ They had some slightly clever gadgets, but nothing you could describe as civilized."

"That was quite odd, wasn't it?" the security manager mused. ${ }^{\alpha}$ The aliens seemed even less advanced than their technology. They didn't even make a token little hollow to sleep in, and just used those fabric pod things to shelter from the sky. No music or anything. And plodding around all over the place in broad daylight."

They all shook their heads and went back to work.

Lee stared at the retreating coastline. The rest of the team had never stopped mocking him since he'd screamed with joy when his trap had caught one of the creatures

stealing their equipment. $\mathrm{OK}$, not since the scream (they'd been just as excited, though they wouldn't admit it now), but since the moment their lights had revealed just a frightened little monkey.

As he'd never shown them the extraordinary astronomical device he had found, Lee couldn't admit that the monkeys had taken that - along with his illegal gun.

Two colleagues came up beside him and started waving. "Bye bye, little hobbits," they crooned. "Sorry we called when you weren't home. Say hello to Gandalf for us."

Lee turned his back on them, on the island of Flores and on the futile search for evidence of the tiny people said to have once lived there.

A few miles away, the security manager took another look at the gun the monkey had brought in. "How does this work?" he pondered. Tapping the barrel experimentally, he began composing a tune. Janet Wright is a freelance journalist and author of books abouthealth, exercise and nutrition. Sometimes her mind wanders. 